International Journal of Linguistics, Literature and Culture
Available online at https://sloap.org/journals/index.php/ijllc/
Vol. 6, No. 2, March 2020, pages: 47-58
$\begin{aligned} & \text { ISSN: 2455-8028 } \\ & \text { https://doi.org/10.21744/ijllc.v6n2.870 }\end{aligned}$

\title{
Cultural Shifting on Agricultural Subak Abian in Jembrana Regency
}

CrossMark

CrossMark

\author{
I Ketut Gede Arta ${ }^{a}$ \\ I Ketut Suda ${ }^{b}$ \\ Ida Bagus Dharmika ${ }^{c}$
}

\section{Article history:}

Submitted: 18 January 2019

Revised: 27 February 2020

Accepted: 09 March 2020

\section{Keywords:}

agricultural culture;

modernism;

shifting;

sociocultural;

Subak Abian;

\begin{abstract}
The paper aims at discussing the shift in agricultural culture. Most Balinese people live in the agricultural sector. They have a variety of traditional knowledge and technology called rural knowledge. Knowledge and technology were used as a foundation by the community in carrying out various activities, including agricultural activities. For example, knowledge of ala-ayuning dewasa to start work in the fields. However, the implementation of the green revolution program by the New Order government, to ensure food availability for 111.8 million residents, from 1969-1974, shifted much of local wisdom value. This study used a qualitative analysis method with an interpretive approach. The results showed several factors that were causing the shift in agricultural culture in Subak Abian, Jembrana Regency, for example, modernism, ideological factors, Dutch colonialism influence, economic development orientation, science, and technology. The shifting process of agricultural culture tends to start from changes in aspects of material infrastructure, then affect of social structure, and ultimately also influence the ideological superstructure aspects. The implications of this shift are seen in social, economic, religious life, and community kinship system.
\end{abstract}

International journal of linguistics, literature and culture (C) 2020. This is an open access article under the CC BY-NC-ND license (https://creativecommons.org/licenses/by-nc-nd/4.0/).

\section{Corresponding author:}

I Ketut Gede Arta,

Universitas Hindu Indonesia, Denpasar, Indonesia.

Email address: ketutgedearta.ap@gmail.com

\footnotetext{
${ }^{a}$ Universitas Hindu Indonesia, Denpasar, Indonesia

${ }^{\mathrm{b}}$ Universitas Hindu Indonesia, Denpasar, Indonesia

${ }^{\mathrm{c}}$ Universitas Hindu Indonesia, Denpasar, Indonesia
} 


\section{Introduction}

The development in Indonesia covers various fields of life, for example, social, cultural, economic, religious, and agricultural life. To guarantee the food needs fulfillment for Indonesian people in the First Five Years Development (1969-1974), the New Order government since 1969 had implemented a green revolution. There was an attempt to develop agricultural technology to increase food production. The green revolution application in Bali is not only limited to wet crop agriculture (subak sawah) but also to dry plant agriculture (subak abian).

The current day in Jembrana Regency subak abian reaches 147 subak, the commodities types produced including coffee, cloves, vanilla, cocoa, bananas, coconut, and others. However, the mainstay commodity is the cocoa crop whose production has succeeded in penetrating the international market. The policy direction of the New Order government, for the Balinese community, including the social subak was affected by the green revolution program. It resulted in a variety of local wisdom values for Balinese people experiencing a shift. Before entering on agricultural technology into the life of the social subak in Bali. The young generation in Bali had been indoctrinated with their parents to be diligent in attending school. Their lives in the future were not solely dependent on the agricultural sector. This phenomenon shows that ideologically in Balinese society including social subak. There has been a shift in ideology from an agrarian ideology to a service ideology. Wherein, the parents wanted their children to become civil servants.

The shifts that occurred in the Balinese community turned out to have very broad dimensions. In a sense, it is not only about agricultural culture, but also targeting a variety of traditional life. As a result, there was a broad and complex detraditionalization. This phenomenon cannot be separated from basic assumptions. They are behind the green revolution, to increase agricultural output, everything smells of the traditional must be removed and replaced with modernism sourced system from Western knowledge and technology (Atmadja, 2010).

There was its development, a massive eviction of traditional values, such as various sekaa (sekaa numbeg, sekaa semal, and other traditional organizations) began to be evicted. Likewise, the original harvest system, farmers harvesting their agricultural products is currently replaced with pajeg system, the plowing system originally used a hoe or animal, replaced with a tractor with more practical considerations, and economical. Even the local wisdom value in the field of farming, which was originally carried out with the mutual assistance and help system has now been replaced by upah system (payment).

If this condition is allowed to continue, it is feared the various local wisdom values for Balinese people which is very valuable will be increasingly displaced by cultural modernism values. It will also, in the end, displace the interpretation of religious values, especially Hinduism. There is partly embraced as the big Balinese community. Three main problems can be formulated. (1) Why has there been a cultural shifting in agricultural subak abian? (2) What the cultural shifting process in agricultural subak abian? (3) What the shift implications in subak abian agricultural culture towards the social system and the religious ceremonial system for Jembrana community?

\section{Materials and Methods}

This study was designed to examine shifting in agricultural culture, especially, the cultural subak abian in processing agricultural land in Jembrana district with a qualitative approach. Qualitative research according to Martono (2015), is research seeks to analyze social life on describing the social world from the interpretive point of individuals viewed. The present research was conducted in Subak Abian, Jembrana Regency, specifically, in Pekutatan Subdistrict with several considerations. First, agricultural production, especially, cocoa, penetrated the international market, thus, it is almost certain the various values of local wisdom used to be the basis of agricultural land management began displaced.

Second, subak is a traditional organization in Bali, including in Pekutatan Subdistrict in carrying out its activities has always been based on traditional values. They are very valuable but are now starting to be touched by economic values, effective, efficient, and pragmatic. Even though the principles have a positive side, the negative element is also very high. Therefore, it can result in the difficulty of subak manners to coordinate between them.

Third, the Pekutatan community was once famous for adopting a strong paternalism and hierarchical understanding with its main characteristic. There are the people who have a helping attitude with mutual principles of sharpening, compassion, and fostering has shifted toward an economic society that prioritizes profit, and monetary system. The shift existence is also one of the reasons for researchers to make subak abian in Jembrana Regency as a research location. 
Data collection for analysis purposes was carried out using observation techniques, interviews, and document studies. According to Satori (2009), observation is a conscious and planned effort to act as collecting data directly and systematically on the object under study. The observations were conducted may not manipulate, stimulate, or give assignments to research subjects to act to obtain certain data. The contextual observations were made on various agricultural activities carried out by farmers in subak abian environment. The interview techniques are meaningful conversations conducted. Two or more people to find out one's opinions, perceptions, feelings, knowledge experience, and sense. In the case of the interview, the researchers try to build interaction and socialization with informants. They can explore the meaning of both the express and implicit in the informant's expression at the time. The interview was conducted (Sutopo, 2006).

The library study technique intended is a data collection technique. It makes things are non-human as the data source. Analysis of documents includes analysis of records (documents), objects, figures, recordings, etc. They are followed closely studying to increase trust and proof eventing. Some documents reviewed are the work program of subak organizations, minutes of meetings, and various other documents related to subak activities, ideas, and subak awig-awig. All collected data is then analyzed continuously from the time of data collection until this research is completed. The data analysis model used is an interactive analysis model of Milles and Huberman (Sugiyono, 2008).

\section{Results and Discussions}

\subsection{Factor of causing the cultural shifting for agricultural Subak Abian}

1) Modernism factor

The modernism idea is used as the basis for solving problems in this research (Collyer, 1997; Eksl \& Métayer, 1986). There is an idea developed by Geertz (2000). The modernization has affected the Indonesian people's lives including Balinese people. It is aimed at global cultural construction, especially, those adopted by the Dutch colonial government. This is due to Indonesia has long been under the Dutch colonial government. The fact is reinforced by Dwipayana (2001), stated the Dutch colonial government hegemony and dominate the Indonesian people, especially, Balinese with their science and technology capital. This method is carried out by the Dutch government in utilizing the mental servant (petani parekan) institutionalized by the kings of Bali, through the ideology of gods and the master-servant link or in the context of Hinduism in Bali called dhana-bhakti.

The people's obedience towards the royal era kings in Bali was not solely due to the physical power possessed. The king was to force the people to submit to them. However, it was also influenced by the Balinese people viewed who considered the king to be deva mawujud (deva nyalantara). The condition was well understood by the Dutch government, then they made Balinese kings as shields of power. As a result, the Balinese not only regard the king as the lord but also consider the Dutch who have a global culture of white as the king's representative who must be respected and obeyed.

Balinese adherence to the colonial authorities like the little result was community began to admire the culture brought on the Dutch government. For their admiration, the Balinese always wanted to internalize and imitate the various patterns of modern community life brought by the Dutch to Bali. This was evident when the New Order government implemented a policy of modernism in agriculture in Indonesia called the green revolution, social subak, including subak abian in Pekutatan Subdistrict, gladly accepted the policy, without any rejection.

2) Ideological factor

The current contextual study and the ideological concept used is an ideology unlike tools of justifying wisdom implemented on the authorities, especially the New Order government. This is due to the authors strongly believe in the implementation of the green revolution program. There was an act of domination carried out by the government at that time and the public, especially the social subak had to accept the program. The ideology behind the government policies was wrapped in the term green revolution was very subtle.

The contextual Marx presented an ideology understanding that members of the subordinate class, namely the working class who farmers guided to imagine their social experiences, social relations, and even themselves, through a set of ideas do not originate from themselves alone. However, it comes from a class that not only has different social, political, and economic interests from them but also often has the opposite direction to the social interests itself. Regarding this framework can be built the New Order government in the

Arta, I. K. G., Suda, I. K., \& Dharmika, I. B. (2020). Cultural shifting on agricultural Subak Abian in Jembrana Regency. International Journal of Linguistics, Literature and Culture, 6(2), 47-58. https://doi.org/10.21744/ijllc.v6n2.870 
context of agricultural development acts as a very important actor in the "stage' of community life, including in the formation of farming communities in Pekutatan Subdistrict, Jembrana Regency.

If it is looked at the changes brought about by the green revolution program, it is indeed focused on agricultural life. The real changes that occurred also target various other social life fields. For example, the harvest system used to be done traditionally through sects or associations. It has now been replaced with a majeg system or a contract system. Likewise, wet agriculture field, the rice harvest system that uses ani-anai (presumption) which involves sekaa manyi and pederep, namely people who carry out mederep activities (bawon system) on the aim of getting harvest wages in the rice form (derepan) is lost because it was replaced with a majeg system.

3) Economic development orientation factor

The orientation of economic development in a country is usually marked by the strengthened relations between political power and the economy. The context of Pekutatan Subdistrict, the people economic development is oriented based on forestry sources, rice farming, and most of all is from organized plantations in subak abian. According to Dharmika (2019), unlike development orientation has placed humans as subjects and economic creatures (homo economicus) who use plantation resources to meet their needs as humans. This is based on historical evidence, since 1908 the kingdoms in Bali under the coordination of the Dutch Government in Jembrana Regency have carried out the conversion of protected forests to plantation areas very high economic value, namely coffee plants, cloves, durian, mangosteen, and chocolate. However, over time the growing influence of modernism, making traditional knowledge of Balinese people unlike began to experience a shift, including traditional knowledge in agriculture. The reason according to Atmadja (2010), modernization hit the Balinese people's lives, not only resulted in changes or shifts in physical culture, and social systems, but also cultural systems. One consequence of such a cultural shift is Balinese are involved in a competition, namely competition for money, power, and prestige.

4) Science and technology factor

There are various limits in the development of science and technology put forward the experts under their respective perspectives. Burhanuddin (1988), stated science is a product of reasoning. A slightly different limitation was conveyed by Hatta (1964), who asserted science is everything is known, both based on one's own experience and based on information. Suriasumantri (1997), stated science is one of human thought result in answering questions addressed to human beings themselves. It is related to be able to understand and appreciate science. Humans must understand science nature. Due to understanding the science nature is often called the ontology aspect of science. It is not only beneficial for efforts to increase human appreciation of the science existence, but also can open one's eyes to the various science deficiencies. As a result, much of the science and traditions of the Indonesian people, especially the Balinese have experienced the marginalization, disappearance, and shift caused by the dynamics of modern society's knowledge.

\subsection{Shifting process of subak abian agricultural culture}

1) Material infrastructure change

Socio-cultural changes generally in human society tend to start from changes in aspects of material infrastructure, affect changes in social structure, and ultimately also affect changes in ideological superstructure aspects. Sanderson (1993), stated aspects of material infrastructure containing raw materials and basic social forms related to human efforts to maintain life and adapt to their environment. The community infrastructure is the most basic component in people's lives. It defines without these components, humans might not be able to physically survive.

The shift in agricultural culture is often not understood for the people in Pekutatan Subdistrict itself. It is in the form of changes in information, equipment, or changes in the form of techniques with which it can facilitate humans in living their lives. Therefore, in developing countries, including Indonesia, development is considered an effective recipe that can treat all forms of diseases. They are considered to impede the ideals of the country towards a just, prosperous, and modern society. The benchmarks of a just, prosperous, and modern society according to Sianipar (2004), are Western culture (modern culture).

This is under the vision formulation of the Pekutatan Government Subdistrict stated 'The realization of a happy, prosperous, just, and cultured Pekutatan community based on faith and piety and supported on the quality natural and human resources, as well as having a determined spirit to carry out sustainable development'. The vision is an ideal hope can be used as inspiration and direction for development in the 
future. Based on the formulation of this vision, it can be understood the development direction cannot be separated from the modernism principles. It proves development in Pekutatan Subdistrict, including the agricultural development is always based on the modernism values whose processes of change occur linearly starting from changes in aspects of material infrastructure, then affecting changes in social structure aspects, and ultimately also affecting changes in ideological superstructure aspects.

The changes in technology, it turns out changes occurred also involve the economic field. Sanderson (1993), stated community economy is a regular system regarding the procurement of goods or services, along with the process of distribution or the process of exchanging goods or services carried out among members community. Production intended in this context is related to various things. Among other things, what goods are produced, who produces, what tools and techniques are used, including who has the basic ingredients enter the production process. In the context of this research, the procurement of goods or services in question is the procurement of goods or services related to the production of dry crop agriculture (subak abian) in Pekutatan Subdistrict, Jembrana Regency. Based on the obtained data during this research, it can be identified the types of plants cultivated on the dry land farmers are clove, mangosteen, coffee, durian, vanilla, chocolate, and even according to some informants, dryland plants which is very current trends are coffee and banana plants.

If it is related to the process of cultural change in subak abian agriculture, it seems as well as follows the process as described by Sanderson (1993). In the change sense, in the technology field, in essence, it will also lead to changes in the economic field. For example, the emergence of various technologies, in the field of transportation and communication, directly or not will affect people's lives in the economic field.

The technological and economic changes also found changes in the field of ecology covered the entire physical environment to which humans must adapt. The environment referred to includes the characteristics of the soil, climate characteristics, rainfall patterns, the nature of plant life, and animals, as well as the availability of natural resources. In strict terminology, ecology is not part of the sociocultural system, but it is an external environment to which the sociocultural system must adapt to it. However, because ecological factors are often crucial determinations for various aspects of social life, ecology is often treated as a basic component of the sociocultural system (Sanderson, 1993).

Concerning Sanderson (1993), and if it is linked to the obtained date data in study location, it cannot be separated from government politics, especially the New Order government. It is stated, therefore, due to the demand for the implementation of regional autonomy is a lawsuit against the concept of fair and equitable development which for more than three decades was pegged as the development ideology of the New Order (Nurrochmat, 2005). Whereas politically, the concept of equitable development is often used as a tool of legitimacy over the dominance of the central government over the allocation and benefits distribution of natural resources exist in each region. This fact is certainly very hurt the sense of justice in various regions, especially, natural resource producers. How is not, people live around oil fields and around forests wherein natural resources are being drained. They still live in poverty and are marginalized.

2) Change of social structure aspects

The aspects of social structure, in this case, include social stratification, political systems, labor division, sexual inequality, and others. Social stratification refers to the group's existence in society are not equal in wealth and power. Piliang (2004), stated in the political, social, and cultural discourse of global capitalism, power is no longer merely sourced from what Foucault (2019), called the power of knowledge. It also comes from the power of speed (power/speed).

Living is a very fast pace of life today. People will be exposed to natural selection based on speed. That is anyone among the community members who are not able to catch up with speed. They then will be crushed by the speed of life on the community itself. Living becomes farming also seems to need to follow the acceleration rhythm if it does not want to be crushed on the roar of the life acceleration. For example, if there are farmers who still survive with manual equipment, with traditional farming techniques, and with a marketing system is not market-oriented. They certainly will not be able to survive (Fulginiti \& Perrin, 1998; Nelson, 2002; O’callaghan et al., 1971).

The community development during the New Order era, there was an increase in the number and levels of formal education owned by the members of indigenous village communities. Unlike an increase in the formal education level of such indigenous village communities, it influences the social community differentiation in the field of work. This is due to many members of indigenous villages who have received high formal education no longer want to take up jobs in the agricultural sector. However, they prefer to work outside of

Arta, I. K. G., Suda, I. K., \& Dharmika, I. B. (2020). Cultural shifting on agricultural Subak Abian in Jembrana Regency. International Journal of Linguistics, Literature and Culture, 6(2), 47-58. https://doi.org/10.21744/ijllc.v6n2.870 
work as farmers, for example, becoming civil servants, becoming private employees, becoming traders, and some are becoming entrepreneurs. They take jobs outside the agricultural sector are successful, earning a new class based on wealth or power (Magnes-Suseno in Atmadja, 2010).

The changes that arise due to a shift in subak abian is not only concerns social stratification but also involves the political system. The political system refers to ways of organizing a society, especially, in terms of maintaining internal laws and regulations or concerning ways to regulate and conduct relationships between members of the community. This will be studied concerning the political system is the changing process on subak abian culture, which is sourced from the political system prevailing in the community wherein the life of the subak takes place.

The political system related to agricultural politics cannot be separated from the scope of state policies, especially, the New Order government. The direction of the New Order government policy in development priorities is to emphasize economic aspects more than social, cultural, and other aspects. Contrasting to the social role in monolithic politics, in the economic field, the New Order government considered more open economic perspectives lead to free markets, which emphasized efficient aspects, and the achievement of optimal profits, compared to other economic systems (Ward \& Kennedy, 1999; Brunt \& Courtney, 1999; Gottlieb \& Chen, 1985). Then, in the field of political life, on adhering to the ideology of developmentalism, to overcome the economic crisis experienced in the Indonesian state in the mid-1960s, the New Order government tried to attract a locus of political control in the country. It defines the government is trying to depoliticize rural communities, on implementing a floating mass strategy. In a sense, the government prohibits the entry of various political activities and organizations into rural areas. All is intended the government can implement a single majority political system (Maliki, 1999; Goodman, 2010; Friedman, 2012).

As a result, the New Order government succeeded in building a single majority political system at providing support to the Golkar (party). Unlike a system, in a long period, the New Order government succeeded in holding power in this beloved Republic, with development programs are top-down planning. As a result, within a relatively long period political system in Indonesia, including in Pekutatan Subdistrict was relatively stable. In the sense, a single majority political system and through the support given to Golkar. Making Golkar at that time able to control the sources and strategic groups that exist in rural areas.

The changes have occurred did not stop, but also related to changes in education. The education referred to this study is formal education, which according to Law No. 20/2003 on the National Education System is a structured and tiered education pathway consisting of basic education, secondary education, and higher education. Education is important for human life because education and culture nation degree can be improved for the international world. How important education in human life has been confirmed in the book of Sarasamusccaya 27 as follows.

Yuvaiva dharmmanvicched yuvā vittamyuvā șrutam

Tiryyagbhawati vai dharba utpatam na cavidyati

Translation:

Due to one's behavior; should be used as well as possible while youth, while the body is strong, it should be used for efforts to demand dharma, artha, and science, because parents are not as strong as young people; for example, it is like an old reed that has fallen, and the end is not sharp anymore.

The sloka actually shows how important education is from a Hindu perspective. Likewise, the viewed community in Pekutatan Subdistrict, Jembrana Regency.

3) Change of psychological superstructure aspect

The aspects of ideological superstructure include general ideology, religious life, science, art, and literature. The term ideology can refer to two meanings, including (1) ideology as a thinking system, belief systems or symbolic practices related to social and political action; (2) the term ideology is also used in the context of justifying power relations are asymmetrical or in other terms called dominance justification. Concerning Sanderson (1993) and Geertz (1977), any human action, including activities in agriculture is inseparable from the ideological superstructure. If we look at the two sociologist's views above, it can be understood the 
ideological superstructure functions as a prescription for action or patterns for acting for a person or group of people in social life.

An ideology is an idea includes values and norms are believed to be true its adherents. Therefore, an idea is articulated as a material practice to organize social realities prevail in society. According to Takwin (2003), social reality is not only in the form of social action but also in verbal language and body language. However, the practice of ideology for people's lives, aspects contradicts the ideology itself is deliberately hidden to justify the ideas included in the ideology they profess (Sadguna et al., 2017; Krishnayana et al., 2019). Therefore, the ideological shift in farming community life at Pekutatan Subdistrict is very difficult to recognize just at looking at the social practices occurred in the people's lives. This is due to an ideology is not only in the form of ideas produce consequences attach and bind humans to the social order. It is marked on welfare, but can also produce status gaps, and power gaps are very prominent, but they are not realized in the community. Due to they have been ideologically anesthetized.

The other changes in ideological aspects, changes also occur in religious life namely concerning beliefs and shared values that intersect on the belief in the existence of a power or something is supernatural. That is in the context of religion people assume beyond their abilities. There are supernatural forces directly or do not affect their lives. The Pekutatan community is seen from the majority religion are Hindus. The details of the population based on religion are as follows. The number of Hindus is 25,566 people consisting of 12,696 male and 12,870 female; Muslim as many as 5,286 people consisting of 2,628 male and 2,658 female; 59 Christians consisting of 22 male and 37 female; 301 Catholics consisting of 148 male and 153 female; 3 Buddhists are consisting of 1 male and 2 female, Konghuchu is absent, while adherents of two people and both are males. So, from 31,217 people in Pekutatan Subdistrict who embraced Hinduism were 25,566 people or around $81.90 \%$ (Profile of Pekutatan Subdistrict, 2015).

Hindu belief that God is unthinkable (acintya), intangible, very noble, and permeates and fills everything in this universe (wyapi wyapaka). Therefore, the existence of God is very difficult for people to imagine, but certain circles, unlike the Wipra or Yogi, can see God with their eyes through samadhi. Those who did, of course, do not need any means to get in touch with God. However, on the contrary for ordinary people needed means to make contact with God Almighty. It is in the form of offerings, namely upakara (Suja, 1999). Worship in the form of such offerings is based on the revelation of the Lord contained in the Bhagavad-Gitā, IX.26 which stated as follows.

'patrai் puspaim phalai் toyam yo me bhaktyā prayacchati tad aham bhakti-upahrtam aśnāmi prayatātmanah'

Bhg. IX.26

Translation:

If someone offers leaves, flowers, fruit or water with love devotion, I will accept it.

Referring to sloka contents, it can be understood offerings or prayers made in Hindus, especially, in Bali always use leaves, flowers, seeds, and water. In its development, it can also be understood the Hindu community in Bali recognizes the value of local wisdom is called desa, kala, and patra meaning, place, time, and condition. This then gives color to the offering facilities made in Hindus, in each region, the form of offerings made in Hindus varies greatly according to them itself. Moreover, religious art also colors Hindu offerings in Bali, making the forms of offerings even more varied.

However, the modernization entry Balinese life does not only result in changes in physical culture and social systems but also in cultural systems, including spirituality aspect namely modern spiritualism. According to Griffin (2005), some aspects which are included in the elements or characteristics of modern spiritualism are the attitude of individualism, dichotomic dualism, futurism, and materialism or economism. Individualism implies in the context of modern spiritualism people no longer understand themself in a communal context but rather in an individualistic context. The change also involves the science field, series techniques for gaining knowledge on basing themselves to observation and experience. This context techniques do not only include techniques and procedures for generating knowledge, but also the accumulative building of knowledge itself. Thus, the knowledge referred to this description is science related to agriculture, especially, dry crop agriculture. On borrowing the ideas of Chambers (1983), it can be

Arta, I. K. G., Suda, I. K., \& Dharmika, I. B. (2020). Cultural shifting on agricultural Subak Abian in Jembrana Regency. International Journal of Linguistics, Literature and Culture, 6(2), 47-58. https://doi.org/10.21744/ijllc.v6n2.870 
understood Balinese have traditional knowledge and technology called 'rural community knowledge', which is passed on from generation to the next generation.

The change also targets the art life in which the socio-cultural component is universal. It defines that contains impressions or symbolic expressions have aesthetic, emotional, or intellectual value for community members or part of society. Likewise, the literary aspect also contains impressions or symbolic expressions have aesthetic, emotional, or intellectual value. The difference with the artistic aspect is in the artistic aspect the aesthetic, emotional, or intellectual symbolic expressions are more physical, while in the literary aspect these expressions are more verbal (oral or written).

Based on the obtained data, it turns out that fine arts unlike building structures, building materials, and types of ornaments used in community buildings, both shrine buildings, and residential buildings also shifted, due to the entry of the modernism era to subak region. For example, for temple buildings or other sacred places, in the past, the community continued to calculate the type of wood that could be used as a building material for the holy place, such as cempaka wood, majegau wood, cendana wood, and others which were normatively regulated in 'Asta Kosala-Kosali-Asta Bumi', current things like are starting to loosen up. Likewise, for house building, in the past people in Pekutatan Subdistrict tended to make houses with traditional Balinese architecture, now many resident's houses are made with modern architectural styles, such as European-style architecture, or a combination of Balinese architecture with European architecture.

\subsection{Shifting implications of subak abian agricultural culture to social, economic, and religious life}

1) Implications for community social life

The implication literally can be interpreted as involvement or the condition involved but not clearly stated (KBBI, 1995). The shift in agricultural culture due to modernism entry into subak abian region had implications for various aspects of the life of the farming community in the region. For social activities in carrying out various jobs, humans often also gather at the bale banjar, at siskamling post (environmental security system command post) or in other public spaces to simply exchange information or simply refresh to relieve fatigue after various activities as a routine. In the 1960s, the Balinese were also known to have a tradition of visiting neighboring homes or other family homes to simply talk or exchange information. However, lately with the inclusion of the green revolution program in subak region in Bali, there have been a variety of cultural shifts, including agricultural culture.

The existence of such shifts, it turns out to have very broad implications on the social life of society. For example, the entry of various modern technologies into the farming community environment in Pekutatan Subdistrict, in addition to some of the implications described above, it turns out the money position has also become an awareness of people's lives in subak region. As a result, subak community is a market or monetarization in all fields of life (Atmadja, 2010). Another consequence is many traditions or systems of social life contradict the principle of marketization slowly, but surely begin to be displaced. For example, the tradition of social credit services through the principle of reciprocity (such as matulungan, ngopin, maselisi and others) began to shift and be replaced by a wage system.

2) Implication for economic life

Discussing economic life, it cannot be separated from human's essence as homo economicus creatures or humans as economic beings. Referring to this idea, human beings as homo economicus, in living their lives cannot escape from various policies in managing various resources, for example, human resources, natural resources, time resources, including money resources. Policies in the process of managing these resources are not solely in the form of setting plans, but also in the form of carrying out various activities to meet community needs, both in the form of family needs and the needs of other social units in the community.

Based on interviewed results to several informants and the results of field observations during the researchers conducting research, it can be understood that economically, the entry of modern technology into subak abian region, in Pekutatan Subdistrict can be stated to have positive implications for the social economy. It is due to the modern agricultural techniques, the harvest can be conducted two to three times per year which previously tended to be only once or at most twice. A shift in the harvesting system, from efforts to harvest its agricultural produce to pajeg system has led to a changing series. For example, pajeg system requires farmers to sell their agricultural products directly in their gardens. Therefore, the harvest is not in the form of coffee, cloves, mangosteen, etc., but in money cash. 
3) Implication for religious life

The religious term in this study refers to the word 'agama [religion]' which means teachings (beliefs). The religion in question is often related to human belief in the existence of God Almighty. Furthermore, in the context of Taylor (1991), stressed that religion is 'the faith in spiritual being' (i.e., belief in spiritual beings) (Jamaludin, 2015). It can be understood in terms of religion is the teachings, instructions, which contain orders or prohibitions, laws, and regulations are believed in supporting community comes from God Almighty who is always used as a reference in behavior and acting daily life-day.

Furthermore, in the context of this study religion is intended to be something contains hopes for people who claim to be religious. That is in the context of religion, religious practices are dimensions concerning worship activities, obedience, or in science form, attitudes, and behaviors are shown to someone who professes to be religiously related to certain theological views. Several descriptions above meant the religious life in the context of this study is concerning, various knowledge, attitudes, and social behavior, related to human relations with God, human relations with fellow human beings, and also concerning human relations with their environment. Based on the obtained data from the interviews and also from observations during the research of the collected data. It can be described the entry of various modern technologies into subak abian region in Pekutatan Subdistrict also has implications for the life diversity of the local farming community.

\section{Conclusion}

Based on the conducted data analysis results, some conclusions can be drawn. First, the cultural shifting in agricultural subak abian, Pekutatan Subdistrict, Jembrana Regency was due to several factors including modernism, ideological, Dutch colonialism influence, development orientation in the economic field, science, and technology. Second, the cultural shifting in agricultural values subak abian environment proceeds through certain stages. The shift occurred starting from changing aspects of material infrastructure, then affecting changes in aspects of social structure, and ultimately also affecting changes in ideological superstructure aspects. Third, the cultural shifting in agriculture from traditional agricultural culture to modern agricultural culture in the subak abian region has implications for various aspects of community life, including social life, religious life, economic life, and including the kinship community system.

\section{Suggestions}

Referring to the conclusions and findings obtained in this study, the suggestions can be obtained are as follows.

1) To the Pekutatan community is advised in responding, reacting or accepting various social changes occurred in the community should be conducted with a little critical rational attitude, because in reality not all traditional knowledge and technology hinder development programs.

2) To the government, in this case, Pekutatan Subdistrict government, it is recommended to always provide counseling to the farmers, not only concerning the mechanisms and techniques of agriculture but also counseling concerning the field of religion and culture, considering the subak in Bali is the core of Hinduism and Balinese culture.

3) Theoretically, this research has not been able to fully reach the cultural shifting in the agricultural subak abian region, Pekutatan Subdistrict, therefore, other researchers interested in this field are advised to conduct further research related to this issue. Therefore, the dimensions that have not been discussed in this research really can be peeled holistically and comprehensively.

\section{Conflict of interest statement}

The authors declared that they have no competing interest.

\section{Statement of authorship}

The authors have a responsibility for the conception and design of the study. The authors have approved the final article.

Acknowledgments

We are grateful to two anonymous reviewers for their valuable comments on the earlier version of this paper.

Arta, I. K. G., Suda, I. K., \& Dharmika, I. B. (2020). Cultural shifting on agricultural Subak Abian in Jembrana Regency. International Journal of Linguistics, Literature and Culture, 6(2), 47-58. https://doi.org/10.21744/ijllc.v6n2.870 


\section{References}

Atmadja, N. B. (2010). Ajeg Bali: gerakan, identitas kultural, dan globalisasi. Penerbit \& distribusi, LKiS.

Brunt, P., \& Courtney, P. (1999). Host perceptions of sociocultural impacts. Annals of tourism Research, 26(3), 493515. https://doi.org/10.1016/S0160-7383(99)00003-1

Burhanuddin Salam, H. (1988). logika Formal (filsafat berfikir). Bina aksara, Jakarta.

Chambers, R. (1983). Membangun Desa Mulai Dari Belakang. LP3ES. Jakarta.

Collyer, F. M. (1997). Technological invention: post-modernism and social structure. Technology in society, 19(2), 195-205. https://doi.org/10.1016/S0160-791X(96)00064-4

Departemen Pendidikan dan Kebudayaan, 1995. Kamus Besar Bahasa Indonesia. Jakarta: Balai Pustaka.

Dharmika, I. B. (2019). Alih Fungsi Lahan dan Implikasinya Terhadap Eksistensi Agama dan Budaya di Bali. Dharmasmrti: Jurnal Ilmu Agama dan Kebudayaan, 10(2), 21-27. https://doi.org/10.32795/ds.v19i2.434

Dwipayana, A. A. (2001). Kelas dan kasta: pergulatan kelas menengah Bali. Lapera Pustaka Utama.

Eksl, R., \& Métayer, G. (1986). Technical modernism and social conservatism: France's communications 'illness'. Futures, 18(2), 258-273. https://doi.org/10.1016/0016-3287(86)90103-5

Elsevier

Foucault, M. (2019). Aesthetics, method, and epistemology: Essential works of Foucault 1954-1984. Penguin UK.

Friedman, S. (2012). Cultural omnivores or culturally homeless? Exploring the shifting cultural identities of the upwardly mobile. Poetics, 40(5), 467-489. https://doi.org/10.1016/j.poetic.2012.07.001

Fulginiti, L. E., \& Perrin, R. K. (1998). Agricultural productivity in developing countries. Agricultural economics, 19(1-2), 45-51. https://doi.org/10.1016/S0169-5150(98)00045-0

Geertz, C. (1977). Penjaja dan Raja Perubahan Sosial dan Modernisasi Ekonomi di Dua Kota Indonesia. (R, Soepomo, terj.). Jakarta: PT. gramedia.

Geertz, C. (2000). The interpretation of cultures. 1973. New York: Basic.

Goodman, M. K. (2010). The mirror of consumption: Celebritization, developmental consumption and the shifting cultural politics of fair trade. Geoforum, 4l(1), 104-116. https://doi.org/10.1016/j.geoforum.2009.08.003

Gottlieb, N. H., \& Chen, M. S. (1985). Sociocultural correlates of childhood sporting activities: their implications for heart health. Social science \& medicine, 21(5), 533-539. https://doi.org/10.1016/0277-9536(85)90037-1

Griffin, D. R. (2005). Visi-Visi Postmodern; Spiritualitas dan Masyarakat. ter. A. Gunawan Admiranto. Yogyakarta.

Hatta, M. (1964). Pengantar ke djalan ilmu dan pengetahuan. Pembangunan.

Jamaludin, A. N. (2015). Agama \& konflik sosial: studi kerukunan umat beragama, radikalisme, dan konflik antarumat beragama. Penerbit Pustaka Setia.

Krishnayana, I. P. A., Suparta, I. N., \& Inggriati, N. W. T. (2019). Impact of application of law no 16/2006 about fisheries and forestry agricultural extension system toward to performance of agricultural extension workers. International Journal of Life Sciences, 3(2), 14-23. https://doi.org/10.29332/ijls.v3n2.295

Maliki, Z. (1999). Penaklukan negara atas rakyat: studi resistensi petani berbasis religio, politik santri terhadap negaranisasi. Gadjah Mada University Press.

Martono, N. (2015). Metode penelitian sosial: konsep-konsep kunci. Jakarta: PT RajaGrafindo Persada.

Nelson, G. C. (2002). Introduction to the special issue on spatial analysis for agricultural economists. Agricultural Economics, 27(3), 197-200. https://doi.org/10.1111/j.1574-0862.2002.tb00116.x

Nurrochmat, D. (2005). Strategi pengelolaan hutan: Upaya menyelamatkan rimba yang tersisa. Pustaka Pelajar.

O’callaghan, J. R., Menzies, D. J., \& Bailey, P. H. (1971). Digital simulation of agricultural drier performance. Journal of Agricultural Engineering Research, 16(3), 223-244. https://doi.org/10.1016/S00218634(71)80016-1

Piliang, Y. A. (2004). Posrealitas: realitas kebudayaan dalam era posmetafisika. Jalasutra.

Sadguna, D. N., Sulistiawati, N. P. A., \& Astiari, N. K. A. (2017). Contributions of household income of farmers as palm crafts outside agriculture sector. International Research Journal of Engineering, IT \& Scientific Research, 3(5), 86-96.

Sanderson, S. K. (1993). Sosiologi makro: sebuah pendekatan terhadap realitas sosial. Penerjemah F. Widjidi dan S Menno). Jakarta: PT Raja Grafindo Persada.

Satori, D. A., \& Komariah, A. (2009). Metodologi penelitian kualitatif. Bandung: Alfabeta, 22.

Sianipar, G. (2004). Mendefenisikan Pascakolonialisme: pengantar menuju wacana pemikiran pascakolonialisme. dalam Hermeneutika Pascakolonial: soal identitas. Editor Mudji Sutrisno dan Hendar Putranto. Yogyakarta: Kanisius.

Sugiyono. (2008). Metode penelitian pendidikan:(pendekatan kuantitatif, kualitatif dan $R \&$ D). Alfabeta. 
Suja, I. W. (1999). Tafsir Keliru terhadap Hindu, Tanggapan untuk Dr. A.G, Honig, J.R. Denpasar: Yayasan Dharma Naradha.

Suriasumantri, J. S. (1997). Ilmu dalam perspektif: Sebuah kumpulan karangan tentang hakekat ilmu. Jakarta: Yayasan Obor Indonesia.

Sutopo, H. B. (2006). Penelitian kualitatif: Dasar teori dan terapannya dalam penelitian. Surakarta: Universitas Sebelas Maret.

Takwin, B. (2003). Akar-akar ideologi: pengantar kajian konsep ideologi dari Plato hingga Bourdieu. Jalasutra.

Taylor, E. B. (1991). A review of local adaptation in Salmonidac, with particular reference to Pacific and Atlantic salmon. Aquaculture, 98(1-3), 185-207. https://doi.org/10.1016/0044-8486(91)90383-I

Ward, C., \& Kennedy, A. (1999). The measurement of sociocultural adaptation. International journal of intercultural relations, 23(4), 659-677. https://doi.org/10.1016/S0147-1767(99)00014-0

Arta, I. K. G., Suda, I. K., \& Dharmika, I. B. (2020). Cultural shifting on agricultural Subak Abian in Jembrana Regency. International Journal of Linguistics, Literature and Culture, 6(2), 47-58. https://doi.org/10.21744/ijllc.v6n2.870 


\section{Biography of Authors}

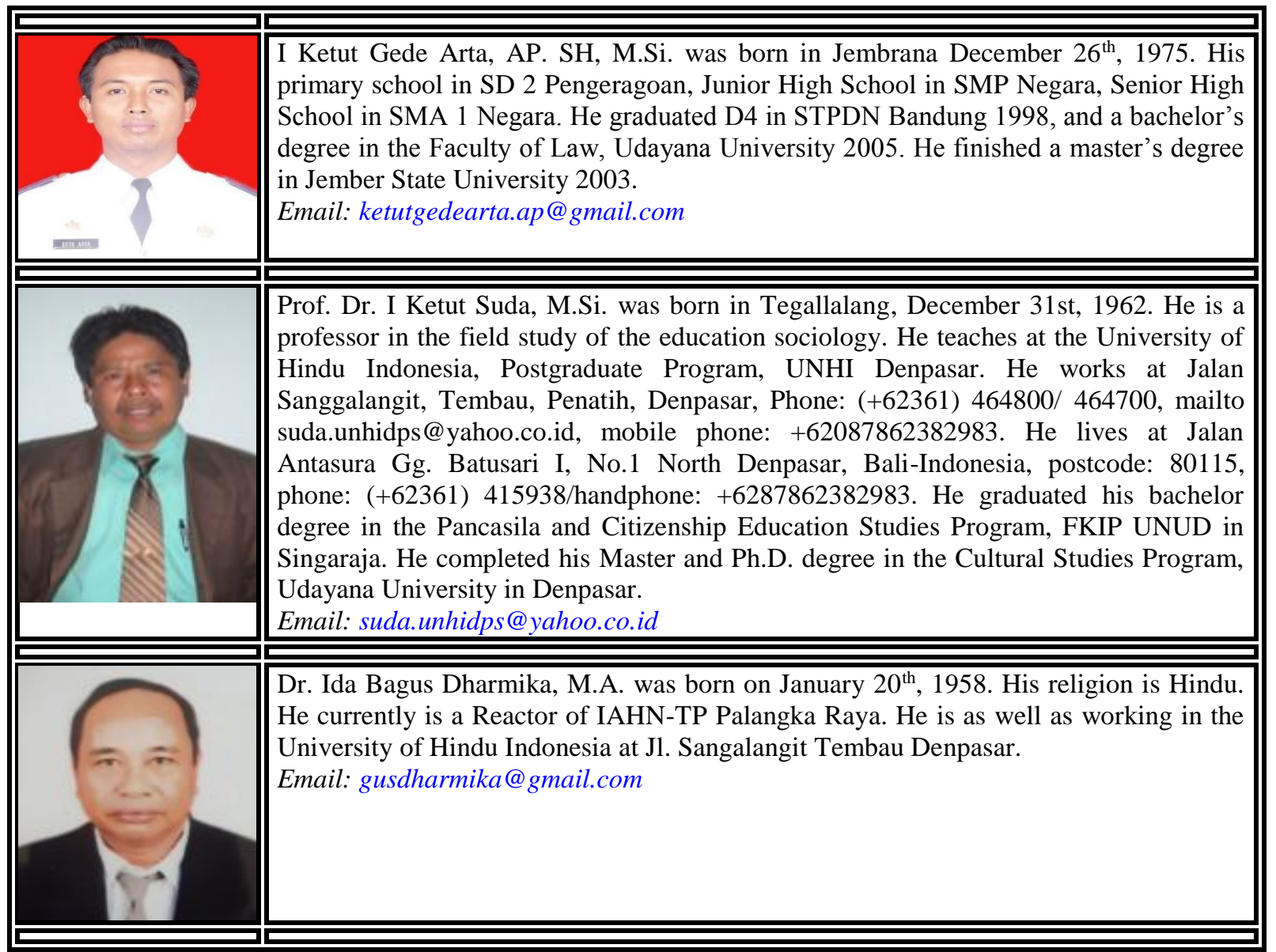

